\title{
PLANTING DEPTH AND MULCH THICKNESS AFFECT ESTABLISHMENT OF GREEN ASH (FRAXINUS PENNSYLVANICA) AND BOUGAINVILLEA GOLDENRAINTREE (KOELREUTERIA BIPINNATA)
}

\author{
By Michael A. Arnold1, Garry V. McDonald², and Donita L. Bryan³
}

\begin{abstract}
Most available information on the effects of planting depths for trees is anecdotal. Testing of interactions with other important cultural practices implemented during landscape establishment is lacking. Green ash (Fraxinus pennsylvanica $\mathrm{H}$. Marshall), a hypoxia-tolerant species, and bougainvillea goldenraintree (Koelreuteria bipinnata A.R. Franchet), a hypoxiaintolerant species, were grown from seed in $2.3 \mathrm{~L}(\# 1)$ containers, which were later transplanted to $9.3 \mathrm{~L}$ (\#3) black plastic containers and grown to a marketable size. Root collars of the plants were maintained level with the surface of the substrate. Green ash (1 May 2001) and bougainvillea goldenraintrees (27 April 2001) were transplanted to clay soil field plots with the root collars at $7.6 \mathrm{~cm}$ (3 in.) above soil grade, at grade, or $7.6 \mathrm{~cm}$ (3 in.) below grade. Planting depths for each species were in factorial combinations with $0,7.6,15.2$, or $22.9 \mathrm{~cm}(0,3,6$, or 9 in.), respectively, of pine bark mulch covering $0.74 \mathrm{~m}^{2}\left(8 \mathrm{ft}^{2}\right)$ of soil beneath each tree. After 2 years, survival of bougainvillea goldenraintrees planted below grade was one-third that of those planted at or above grade. Survival and trunk diameter responses interacted with planting depth and mulch thickness for green ash. Planting below grade in combination with mulching reduced survival of green ash 25\% to 50\% after 3 years. Mulch applications reduced trunk diameters of green ash trees planted at or above grade. Mean soil water potentials were less negative with $7.6 \mathrm{~cm}$ ( 3 in.) of mulch $(-5.8 \mathrm{kPa})$ compared to bare soil $(-9.1 \mathrm{kPa})$, but increasing the mulch thickness to $22.9 \mathrm{~cm}(9$ in.) inhibited penetration of irrigation water/rainfall $(-16.2 \mathrm{kPa})$. These data suggest that planting with the root collar at or above grade enhances survival and growth potential of green ash and bougainvillea goldenraintree relative to planting below grade and that mulch applications should be only at thin layers sufficient to inhibit weeds. Bougainvillea goldenraintrees were more susceptible to the adverse effects of below-grade installation and excess mulch applications than were green ash trees.
\end{abstract}

Key Words. Fraxinus pennsylvanica; hypoxia; Koelreuteria bipinnata; pine bark mulch; planting depth; transplant establishment; tree planting.

Planting depth information is mostly anecdotal (Watson and Himelick 1997). One of the more common reasons given for planting trees deeply is to avoid windthrow. Likewise, trees are sometimes intentionally planted below grade to lessen root conflicts with infrastructure (McPherson et al. 2001). Those studies that have been conducted on planting depth yielded somewhat variable results depending on the soil type, type of planting stock, length of study, and tree species in question (Drilias et al. 1982; Browne and Tilt 1992; Broschat 1995; Broschat and Meerow 2000; Arnold and McDonald 2002; Gilman and Grabosky 2004). In general, the heavier the soil and more susceptible the species to hypoxia (reduced oxygen levels) or anoxia (lack of oxygen), the more likely were plants with root collars below the soil line to grow poorly.

Growth and survival of balled-and-burlapped sugar maple (Acer saccharum H. Marshall) and pigmy date palm (Phoenix roebelenii J. O'Brien) were adversely impacted by planting the root collars below grade (Drilias et al. 1982; Broschat 1995). In contrast, Browne and Tilt (1992) reported improved survival and growth during the first year after transplant of red maples (Acer rubrum L.) planted 5.1 to $10.2 \mathrm{~cm}$ ( 2 to 4 in.) below grade in a clay-loam soil and found no adverse effects with root collars as much as 15.3 cm (6 in.) below grade. Browne and Tilt (1992) did however report first-year growth reductions on the same site for Virginia pines (Pinus virginiana) and flowering dogwoods (Cornus florida L.) planted below grade. Planting stock type and size of stock were not reported.

Gilman and Grabosky (2004) reported only transitory drought stress on $7.6 \mathrm{~cm}$ ( 3 in.) caliper, container-grown Quercus virginiana planted below grade in a sandy soil, with subsequent reduced drought stress on below-grade trees later during the first growing season. Although this study used larger trees than the other studies, it was of very short duration, including only data for the first 7 months after transplant.

Repeated transplanting of trees to successively larger containers or repeated mounding of soil in field nurseries can lead to trees that are produced with root collars significantly below the substrate surface in the marketed container or dug root ball (Ball 1999). In addition, homeowners and landscape installers tend to plant trees with the root collars at a greater depth than the existing soil 
grade in an attempt to prevent trunk leaning or blow-over of the newly transplanted trees. Alternatively, it is sometimes recommended that when planting in heavy clay or poorly drained soils that the top of the root ball be planted slightly above grade to avoid having the root collar or trunk of the tree exposed to wet soil for extended periods of time (Pirone et al. 1988; Arnold 2002). Inadequately compacted fill soil in the bottom of planting holes or decomposition of organic substrates with container-grown stock can result in settling of the root collar below grade after planting. All of these practices may result in trees planted at depths other than that which would have occurred if the tree seedling had naturally germinated and grown on the site.

Much more is known about the effects of mulching (Green and Watson 1989; Watson and Himelick 1997; Duryea et al. 1999; Carlson 2002). Most studies report beneficial effects relative to bare soil treatments, such as increased moisture retention in the soil beneath the mulch, improved weed suppression, temperature modification, or improved soil quality (Ashworth and Harrison 1983; Stinson et al. 1990; Greenly and Rakow 1995). However, Carlson (2002) warns of the adverse effects of excessive mulch applications and encourages the concept of varying mulch thickness and textural composition with increased need for oxygen penetration in heavy, poorly drained soils. More is not necessarily better, and there is no evidence to support the widespread practices of piling "mulch volcanoes" around the trunks of newly transplanted trees. Placing mulch too deeply against trunks can result in damage to bark and phloem tissues (Ball 1999). Other concerns with mulches are variation in nutrient content, allelopathy, and decomposition properties (Duryea et al. 1999; Foshee et al. 1999). Likewise, pine bark mulch can result in greater reflectance of longwave radiation from mulch surfaces than from bare soil or turfgrasses, creating a greater heat load in the canopy (Zajicek and Heilman 1991). Alternatively, pine bark mulch may help to buffer soil temperature fluctuations (Montague and Kjelgren 2004).

In preliminary results with bougainvillea goldenraintree and green ash, Arnold and McDonald (2002) found surprisingly strong differential responses in growth and survival during the first year after transplanting to both planting depth and mulch thickness on a heavy clay soil. Gilman and Grabosky (2004) reported mixed water stress responses during the first growing season for live oaks (Quercus virginiana Mill.) transplanted at various depths. Aside from these short-term reports, no research information on the interactions among these two important tree establishment practices was found. Thus, the purpose of this research project was to (1) document the potential for interactions among planting depths and the thickness of mulch applications on the establishment of container-grown trees, and (2) compare responses to varied planting depths between a flood-tolerant and a flood-intolerant species.

\section{MATERIALS AND METHODS}

Two tree species, Koelreuteria bipinnata (hypoxia intolerant) and Fraxinus pennsylvanica (hypoxia tolerant), were chosen for their differential responses to soils with seasonally poor drainage (Arnold 2002). Trees of both species were produced on site at the Texas A\&M University Nursery/Floral Field Laboratory (College Station, Texas, U.S.) to ensure that the root collars were at the surface of the container substrate. Seedlings were grown in an outdoor container nursery utilizing a commercial pine bark-based substrate (3 pine bark: 1 peat moss: 1 coarse builders sand, by volume) in 9.3 L (\#3) black plastic containers (Lerio Corp., El Campo, TX). The substrate was amended with $6.8 \mathrm{~kg} \mathrm{~m}^{-3}\left(12 \mathrm{lb} \mathrm{yd}^{-3}\right)$ 18N-3P-8.3K controlled-release fertilizer (18-7-10, Sierrablen, Scotts Corp., Marysville, OH), $3.4 \mathrm{~kg} \mathrm{~m}^{-3}$ (6 lb $\mathrm{yd}^{-3}$ ) of dolomite (Vulcan Materials Co., Tarrant, AL), $1.7 \mathrm{~kg}$ $\mathrm{m}^{-3}\left(3 \mathrm{lb} \mathrm{yd}^{-3}\right)$ of gypsum (Standard Gypsum Corp., Fredericksburg, TX), and $0.68 \mathrm{~kg} \mathrm{~m}^{-3}\left(1.5 \mathrm{lb} \mathrm{yd}^{-3}\right)$ of micromax micronutrients (Scotts Corp.). Irrigation water for the nursery was injected with concentrated sulfuric acid (Scholle Corp., Northlake, IL) to lower water pH to 6.5 and with a 24N-3.5P-13.2K (24-8-16, 7.19\% ammonium nitrate, $7.21 \%$ urea, and $9.60 \%$ nitrate, Scotts Corp.) water-soluble fertilizer to yield a concentration of $50 \mathrm{mg} \mathrm{L}^{-1}(50 \mathrm{ppm}) \mathrm{N}$. Trees were staked and trained to a central leader.

Trees were transplanted to adjacent field plots on 27 April 2001 (K. bipinnata) or 1 May 2001 (F. pennsylvanica). At transplanting, K. bipinnata averaged $88 \mathrm{~cm}$ (35 in.) in height and $15.3 \mathrm{~mm}$ (0.60 in.) in trunk diameter at $15 \mathrm{~cm}$ (6 in.) above the root collar, while F. pennsylvanica averaged $126 \mathrm{~cm}$ (50 in.) and $14.9 \mathrm{~mm}(0.55 \mathrm{in}$.), respectively. Koelreuteria bipinnata (84 trees) and F. pennsylvanica (120 trees) were established on $0.91 \mathrm{~m}(3 \mathrm{ft})$ within-row and $3.1 \mathrm{~m}(10 \mathrm{ft})$ between-row spacings in Brazos County, Texas. Field plots contained a Boonville Series, Boonville fine sandy loam, fine, montmorillic thermic ruptic-vertic albaqualfs ( $\mathrm{pH}$ 9.1, bulk density $1.51 \mathrm{~g} \mathrm{~cm}^{-3}, 61 \%$ sand, $11 \%$ clay, $28 \%$ silt) underlain at a 15.2 to $30.5 \mathrm{~cm}$ (6 to $12 \mathrm{in}$.) depth with a hard clay pan.

To ensure uniformity of disturbed soil volume within the planting holes, the holes were dug to accommodate the deepest planting depth possible (from the root collar to bottom of the root ball plus $7.6 \mathrm{~cm}$ [3 in.]) using a $45.7 \mathrm{~cm}$ (18 in.) diameter auger mounted on a Dingo ${ }^{\circledR}$ compact utility loader (The Toro Co., Bloomington, MN). This procedure also ensured that the clay pan was punctured to the same depth in all holes. Sides of the holes were scarred to avoid glazing and the backfill tamped firmly to achieve the desired planting depths. Final planting depths placed the root collars $7.6 \mathrm{~cm}$ ( 3 in.) below grade, at grade, or $7.6 \mathrm{~cm}$ (3 in.) above grade. The excised native soil was used as backfill during planting. Soil water potential was monitored using tensiometers (Model 2725 JetFill Tensiometers, Soil Moisture Equipment Corp., Santa Barbara, CA) inserted to a 
$15.2 \mathrm{~cm}$ (6 in.) depth. Trees were irrigated daily for the first 4 weeks using drip tape (T-Tape ${ }^{\circledR}$, T-Systems International Inc., San Diego, CA) at 10 psi to maintain moisture in the transplanted root balls and afterward when soil water potentials reached $-1.5 \mathrm{kPa}$ ( -15 bars) in nonmulched control plots. The drip tape was located above the mulch.

In factorial combinations with the three planting depths, four mulch thickness treatments were established. A 0.74 $\mathrm{m}^{2}\left(8 \mathrm{ft}^{2}\right)$ area around each tree was mulched to a depth of $0,7.6,15.2$, or $22.9 \mathrm{~cm}(0,3,6$, or $9 \mathrm{in}$.) with a mixed particle size, commercial, shredded pine bark mulch (Southwood Valley Turf, College Station, TX). Mulch treatments were separated between plants via two $0.61 \mathrm{~m}(2 \mathrm{ft})$ long, double-stacked, $10 \mathrm{~cm}$ (4 in.) tall CCA-treated landscape timbers (Lowe's, Bryan, TX). Mulch was replenished in the spring and fall of each year to maintain the desired treatment levels. Three sets of plants with one of each mulching thickness treatment were randomly chosen to monitor soil water potentials adjacent to the root ball. Soil water potentials in mulch treatments were monitored throughout the first growing season.

Both species remained in the field under irrigation for 2 years after planting - a time frame in which the trees should have been well established in USDA plant hardiness zone 8b (Gilman 1997). After the second year, the K. bipinnata study was terminated due to low survival of some treatments. During the third growing season, irrigation was not provided to F. pennsylvanica to confirm that these plants were fully established. Height, trunk diameters at $15 \mathrm{~cm}$ (6 in.) above the soil surface, survival, and the percentage of the canopy exhibiting stress symptoms (chlorosis, marginal necrosis, and/ or premature leaf senescence) were measured at transplant to the field and at the end of each growing season.

Each species was treated as a separate experiment. The statistical design was a randomized complete block design consisting of a factorial of three planting depths $\times$ four mulching thicknesses for each species. In the experiment with F. pennsylvanica, there were ten blocks containing a single plant replication of each treatment combination, whereas with K. bipinnata there were eight blocks. A square root transformation was performed on the percentage data to normalize variation prior to analysis. The results of this analysis were converted back to percentages for presentation in tabular form. Data were analyzed using the general linear models procedures in the SAS System for Windows, Release 8.01 (SAS Institute, Inc., Cary, NC).

\section{RESULTS AND DISCUSSION}

\section{Green Ash}

Green ash did not exhibit any significant $(P \leq 0.05)$ interactions between planting depth and mulch thickness involving time after planting for height or trunk diameter (Table 1). Height growth responses for green ash were significant
$(P \leq 0.05)$ only for main effects of time, mulch, and planting depth, with no two- or three-way interactions significant for this variable (Table $1^{*}$ ). Across planting depths and mulch treatments, mean green ash trunk diameter increased for all 3 years after transplanting, while height growth increased slowly during the first 2 years and more rapidly in the third (Table 1).

The equal or greater increase in height and trunk diameter after cessation of irrigation in the third year suggests that the trees were fully established in the landscape. This finding would be consistent with Gilman's (1997) model of establishment in USDA plant hardiness zone 8b. With the exception of the $7.6 \mathrm{~cm}$ (3 in.) below-grade planting depth treatment, mulching had a consistent negative effect on green ash height growth when pine bark mulch depths were maintained at greater than a $7.6 \mathrm{~cm}(3$ in.) depth (Table 1). The apparent inconsistency of no reduction in height or trunk diameter due to mulch thickness when green ash were planted below grade may have been an artifact of the much lower survival of trees that were planted below grade and then mulched. Perhaps only the more vigorous trees survived, biasing the growth response to this treatment because the smaller, less vigorous trees in the mulch treatments died in the second and third years of the study.

Mean height after three growing seasons for green ash was reduced for trees transplanted $7.6 \mathrm{~cm}$ ( 3 in.) below grade (156 cm [61 in.]) compared to those planted at grade (166 cm [65 in.]), and planting $7.6 \mathrm{~cm}$ (3 in.) above grade slightly increased height growth (172 cm [68 in.]).

Likewise, the proportion of the canopy exhibiting transplant stress symptoms during the first year following transplanting (Table 2) increased by $12 \%$ to $26 \%$ for plants with mulch depths of $7.6 \mathrm{~cm}$ (3 in.) or greater. Gilman and Grabosky (2004) reported that $7.6 \mathrm{~cm}$ (3 in.) thick hardwood mulch treatments impeded light irrigation or rainfall events from penetrating to the planted root balls, but they found no effect of planting depth on container-grown live oak trunk diameter at 7 months after transplant. This apparent lack of response during the first growing season for live oaks is not inconsistent with the results of green ash in the current study because differential growth and survival responses to planting depth were minimal for green ash during the first growing season, but they were manifested more strongly the second and third years after transplant (Table 1).

Significant $(P \leq 0.05)$ two-way interactions among planting depth and time after transplant, mulch thickness and time after transplant, and planting depth and mulch thickness were present for green ash survival (Table 1). Green ash survival declined much more rapidly over time after transplant for trees planted below grade than those at

*Tables appear on pages 168-170. 
grade or above grade if they received any mulch application (Table 1). Differential responses increased over time after planting. After three growing seasons in the field, planting a mere $7.6 \mathrm{~cm}$ (3 in.) below grade in combination with mulching resulted in as much as $60 \%$ greater losses with green ash, a species often thought to be tolerant of urban soils (Arnold 2002). Planting green ash above grade resulted in slight improvements in height and trunk diameter growth but did not affect survival compared to those planted at grade (Table 1). Broschat and Meerow (2000) indicated that deep planting of palms (family Arecaceae) often resulted in reduced survival and root growth, increased water stress symptoms, and iron or manganese deficiency symptoms in the canopy. This finding was in agreement with Browne and Tilt's (1992) short-term results with Virginia pines (Pinus virginiana) and flowering dogwoods (Cornus florida) but contrasted with their reported improved growth and survival of red maples (Acer rubrum L.) planted 5.1 to $10.2 \mathrm{~cm}$ (2 to 4 in.) below grade and a lack of adverse effects with red maples when root collars were as much as $15.3 \mathrm{~cm}$ (6 in.) below grade.

Pine bark mulch depths of as little as $7.6 \mathrm{~cm}$ (3 in.) decreased green ash survival over time (Table 1). Differential responses in green ash survival to mulch thickness appeared to increase over time (Table 1). Mulching accentuated losses associated with planting the root collar below grade. Trees planted above grade had only very slight decreases in survival associated with increasing mulch thickness (Table 1). When planted at grade, green ash survival was similar regardless of mulch thickness, although growth was reduced. It is unclear why survival of trees planted below grade appeared to be poorest at intermediate rather than the more excessive mulch applications. Interestingly, this result is essentially an inverse response pattern to that of soil water potential when averaged over time, which was numerically less negative (moister) with $7.6 \mathrm{~cm}$ (3 in.) of pine bark mulch (Table 3 ) but then became statistically more negative (drier) as mulch thickness increased to $22.9 \mathrm{~cm}$ (9 in.). Perhaps greater mulch application was inhibitory to penetration of irrigation water and/or natural precipitation, which would be in agreement with Gilman and Grabosky's (2004) results when light irrigation was used in combination with hardwood bark applications.

\section{Bougainvillea Goldenraintree}

In general, adverse growth responses to below-grade planting were more accentuated with bougainvillea goldenraintree than with green ash (Tables 1 and 2). Averaged across mulch thicknesses, two-way interactions $(P \leq 0.05)$ were present with bougainvillea goldenraintree among planting depth and time after transplant for trunk diameter, height, and survival (Table 1). Trunk diameter increased for trees transplanted at grade, and initially for trees transplanted $7.6 \mathrm{~cm}$ ( 3 in.) above grade (Table 1). Bougainvillea goldenraintrees planted $7.6 \mathrm{~cm}$ ( 3 in.) below grade had only a slight increase in trunk diameter during the two growing seasons after transplant. Averaged across mulch thicknesses, height growth of bougainvillea goldenraintree was reduced by planting either above or below grade compared to planting at grade (Table 1).

Some dieback, perhaps due to tip dieback in a later winter freeze, occurred in all bougainvillea goldenraintree treatments. Survival of bougainvillea goldenraintree was not as strong as with green ash, across treatments (Table 1). By the end of the second year, survival decreased so severely in bougainvillea goldenraintrees that were planted below grade that the experiment with this species was not continued in the third year. While planting above grade with green ash only slightly improved survival compared to trees planted at grade, transplanting bougainvillea goldenraintrees $7.6 \mathrm{~cm}$ (3 in.) above grade improved survival by as much as $40 \%$ as long as no mulch was applied (Table 1). This result may be a reflection of the poorer tolerance of bougainvillea goldenraintree to poorly drained soils (Arnold 2002).

Although planting slightly above grade appeared to be beneficial in our experiments, Broschat and Meerow (2000) reported that palms planted with root initiation zones as little as $2.5 \mathrm{~cm}$ ( $1 \mathrm{in}$.) above grade can exhibit problems with root desiccation before they can grow into the soil. Likewise, Gilman and Grabosky (2004) found few advantages to transplanting live oaks in a sandy soil above grade, suggesting that testing among a range of species is needed on a variety of soil types before sweeping recommendations can be provided. In general, pine bark mulch tended to reduce survival (Table 1) and increase symptoms of foliar stress (Table 2) of bougainvillea goldenraintrees, particularly when trees were planted above or below grade, rather than at grade. No termite activity was observed within the mulch during the course of this study.

\section{CONCLUSIONS}

In general, planting either green ash or bougainvillea goldenraintree as little as $7.6 \mathrm{~cm}$ ( 3 in.) below grade was often detrimental to survival. Planting above grade by 7.6 $\mathrm{cm}$ (3 in.) improved survival of bougainvillea goldenraintree compared to at-grade planting more so than with green ash as long as mulch levels were not excessive. Advantages to planting above grade were minimal in terms of height or trunk diameter growth for green ash over 3 years and bougainvillea goldenraintrees over 2 years, but planting below grade was very detrimental to survival if done in combination with pine bark mulch applications.

Survival of both species in this study was usually best when bare soil was used, compared to applications of pine bark mulch. However, these plots were diligently maintained in a weed-free condition via careful hand weeding (no string 
trimmers were used) and use of herbicides. Mulches can be effective weed suppressants; hence, under different weed control regimes, or with different soils, environmental conditions, mulch types, or irrigation regimes, responses to mulches may vary.

Our results document the potentially damaging effects on tree growth and survival of planting even slightly below grade, particularly in combination with excess pine bark mulch applications. These adverse effects can persist for at least 3 years after transplanting and, in many cases, differential responses became more pronounced over time.

\section{LITERATURE CITED}

Arnold, M.A. 2002. Landscape Plants for Texas and Environs (2nd ed.). Stipes Publishing, Champaign, IL. 1088 pp.

Arnold, M.A., and G.V. McDonald. 2002. Planting depth and mulching depth: Do they matter? Southern Region American Society for Horticultural Sciences, 2-5 Feb. 2002, Orlando, FL. HortScience 37:1163-1164 (abstract).

Ashworth, S., and H. Harrison. 1983. Evaluation of mulches for use in the home garden. HortScience 18:180-182.

Ball, J. 1999. Plant health care CEU series part VI: Tree planting - The foundation of PHC. Arborist News 8(1):53-58.

Broschat, T. 1995. Planting depth affects root growth and nutrient content of transplanted pygmy date palms. HortScience 30:1031-1032.

Broschat, T.K., and A.W. Meerow. 2000. Ornamental Palm Horticulture. University Press of Florida, Gainesville, FL. $255 \mathrm{pp}$.

Browne, C., and K. Tilt. 1992. Effects of planting depth on three ornamental trees. Proc. South. Nurserymen's Res. Conf. 37:123-125.

Carlson, C.R. 2002. Mulch, part 2: Go wide, not deep. Arborist News 11(1):35-40.

Drilias, M.J., J.E. Kuntz, and G.I. Worf. 1982. Collar rot and basal canker of sugar maple. J. Arboric. 8:29-33.

Duryea, M.L., R.J. English, and L.A. Hermansen. 1999. A comparison of landscape mulches: Chemical, allelopathic, and decomposition properties. J. Arboric. 25:88-97.

Foshee, W.G. III., W.D. Goff, M.G. Patterson, K.M. Tilt, W.A. Dozler, L.S. Tucker, and J.S. Bannon. Organic mulches affect soil and leaf nutrient levels of young pecan trees. J. Arboric. 25:81-83.

Gilman, E.F. 1997. Trees for Urban and Suburban Landscapes. Delmar Publishers, Albany, NY. 662 pp.

Gilman, E.F., and J. Grabosky. 2004. Mulch and planting depth affect live oak (Quercus virginiana Mill.) establishment. J. Arboric. 30:311-317.
Green, T.L., and G.W. Watson. 1989. Effects of turfgrass and mulch on the establishment and growth of bare-root sugar maples. J. Arboric. 15:268-272.

Greenly, K.M., and D.A. Rakow. 1995. The effect of wood mulch type and depth on weed and tree growth and certain soil parameters. J. Arboric. 21:225-232.

McPherson, E.G., L.R. Costello, and D.W. Burger. 2001. Space wars: Can trees win the battle with infrastructure? Arborist News 10(3):21-24.

Montague, T., and R. Kjelgren. 2004. Energy balance of six common landscape surfaces and the influence of surface properties on gas exchange of four containerized tree species. Scientia Hortic. 100:229-249.

Pirone, P.P., J.R. Hartman, M.A. Sall, and T.P. Pirone. 1988. Tree Maintenance (6th ed.). Oxford University Press, New York, NY. 514 pp.

Stinson, J.M., G.H. Brinen, D.B. McConnell, and R.J. Black. 1990. Evaluation of landscape mulches. Proc. Flor. State Hortic. Soc. 103:372-377.

Watson, G.W., and E.B. Himelick. 1997. Principles and Practice of Planting Trees and Shrubs. International Society of Arboriculture, Champaign, IL. 199 pp.

Zajicek, J.M., and J.L. Heilman. 1991. Transpiration by crape myrtle cultivars surrounded by mulch, soil, and turfgrass surfaces. HortScience 26:1207-1210.

Acknowledgments. This project was funded in part by the Texas Agricultural Experiment Station and grants from the TREE Fund, the J. Frank Schmidt Family Charitable Foundation, and Texas Ornamental Enhancement Endowment. Mention Trec Rescarch \& Education Endownent Fund of a trademark, proprietary product, or vendor does not constitute a guarantee or warranty of the product by the author, the Texas A\&M University, or the Texas Agricultural Experiment Station, and does not imply its approval to the exclusion of other products or vendors that also may be suitable.

${ }^{1 *}$ Professor of Landscape Horticulture

${ }^{2}$ Research Associate and Ph.D. Candidate

${ }^{3}$ Graduate Research/Teaching Assistant and Ph.D. Student

Texas AEM University

Department of Horticultural Sciences

M.S. 2133

College Station, TX 77843-2133, U.S.

"Corresponding author (ma-arnold@tamu.edu). 
Table 1. Growth responses of Fraxinus pennsylvanica and Koelreuteria bipinnata seedlings grown in 9.3 L (\#3) containers and then transplanted to field plots with the root collar at grade, $7.6 \mathrm{~cm}(3 \mathrm{in}$.) above grade, or $7.6 \mathrm{~cm}$ ( 3 in.) below grade and maintained in a factorial combination with $0,7.6,15.2$, and $22.9 \mathrm{~cm}(0,3,6$, or 9 in.) layers of mulch over the $0.74 \mathrm{~m}^{2}\left(8 \mathrm{ft}^{2}\right)$ root zone.

\begin{tabular}{|c|c|c|c|c|c|c|c|c|}
\hline \multirow[b]{2}{*}{$\begin{array}{l}\text { Years in } \\
\text { the field }\end{array}$} & \multirow[b]{2}{*}{ Planting depth } & \multirow[b]{2}{*}{$\begin{array}{l}\text { Mulch } \\
\text { thickness (mm) }\end{array}$} & \multicolumn{3}{|c|}{ Fraxinus pennsylvanica } & \multicolumn{3}{|c|}{ Koelreuteria bipinnata } \\
\hline & & & Height $(\mathrm{cm})$ & $\begin{array}{l}\text { Trunk } \\
\text { diameter }(\mathrm{mm})\end{array}$ & Survival (\%) & Height $(\mathrm{cm})$ & $\begin{array}{l}\text { Trunk } \\
\text { diameter (mm) }\end{array}$ & Survival (\%) \\
\hline \multirow[t]{12}{*}{0} & $7.6 \mathrm{~cm}$ & 0 & $125 \pm 10^{z}$ & $15 \pm 2$ & $100 \pm 8$ & $79 \pm 8$ & $13 \pm 2$ & $100 \pm 13$ \\
\hline & below grade & 7.6 & $121 \pm 10$ & $15 \pm 2$ & $100 \pm 8$ & $81 \pm 9$ & $15 \pm 2$ & $100 \pm 14$ \\
\hline & & 15.2 & $118 \pm 11$ & $14 \pm 2$ & $100 \pm 8$ & $90 \pm 9$ & $16 \pm 2$ & $100 \pm 14$ \\
\hline & & 22.9 & $121 \pm 11$ & $14 \pm 2$ & $100 \pm 8$ & $91 \pm 10$ & $16 \pm 2$ & $100 \pm 15$ \\
\hline & At grade & 0 & $121 \pm 10$ & $15 \pm 2$ & $100 \pm 8$ & $89 \pm 9$ & $16 \pm 2$ & $100 \pm 14$ \\
\hline & & 7.6 & $129 \pm 10$ & $15 \pm 2$ & $100 \pm 8$ & $88 \pm 9$ & $16 \pm 2$ & $100 \pm 14$ \\
\hline & & 15.2 & $129 \pm 10$ & $15 \pm 2$ & $100 \pm 8$ & $90 \pm 9$ & $16 \pm 2$ & $100 \pm 13$ \\
\hline & & 22.9 & $138 \pm 10$ & $15 \pm 2$ & $100 \pm 8$ & $85 \pm 10$ & $14 \pm 2$ & $100 \pm 15$ \\
\hline & $7.6 \mathrm{~cm}$ & 0 & $120 \pm 11$ & $15 \pm 2$ & $100 \pm 8$ & $92 \pm 10$ & $15 \pm 2$ & $100 \pm 15$ \\
\hline & above grade & 7.6 & $131 \pm 10$ & $15 \pm 2$ & $100 \pm 8$ & $92 \pm 9$ & $16 \pm 2$ & $100 \pm 14$ \\
\hline & & 15.2 & $128 \pm 9$ & $15 \pm 2$ & $100 \pm 7$ & $88 \pm 8$ & $16 \pm 2$ & $100 \pm 13$ \\
\hline & & 22.9 & $128 \pm 10$ & $15 \pm 2$ & $100 \pm 8$ & $89 \pm 9$ & $16 \pm 2$ & $100 \pm 14$ \\
\hline \multirow[t]{12}{*}{1} & $7.4 \mathrm{~cm}$ & 0 & $124 \pm 10$ & $17 \pm 2$ & $100 \pm 8$ & $89 \pm 13$ & $14 \pm 3$ & $38 \pm 13$ \\
\hline & below grade & 7.6 & $129 \pm 10$ & $19 \pm 2$ & $100 \pm 8$ & $86 \pm 24$ & $15 \pm 6$ & $14 \pm 14$ \\
\hline & & 15.2 & $114 \pm 12$ & $15 \pm 2$ & $89 \pm 8$ & $132 \pm 24$ & $19 \pm 6$ & $14 \pm 14$ \\
\hline & & 22.9 & $117 \pm 11$ & $16 \pm 2$ & $100 \pm 8$ & - & - & $0 \pm 16$ \\
\hline & At grade & 0 & $129 \pm 10$ & $20 \pm 2$ & $100 \pm 8$ & $110 \pm 10$ & $19 \pm 2$ & $86 \pm 14$ \\
\hline & & 7.6 & $125 \pm 10$ & $16 \pm 2$ & $90 \pm 8$ & $129 \pm 12$ & $20 \pm 3$ & $57 \pm 14$ \\
\hline & & 15.2 & $133 \pm 10$ & $18 \pm 2$ & $100 \pm 8$ & $115 \pm 12$ & $20 \pm 3$ & $50 \pm 13$ \\
\hline & & 22.9 & $144 \pm 10$ & $19 \pm 2$ & $100 \pm 8$ & $133 \pm 17$ & $19 \pm 4$ & $33 \pm 15$ \\
\hline & $7.6 \mathrm{~cm}$ & 0 & $135 \pm 10$ & $20 \pm 2$ & $100 \pm 8$ & $109 \pm 10$ & $19 \pm 2$ & $100 \pm 15$ \\
\hline & above grade & 7.6 & $138 \pm 10$ & $20 \pm 2$ & $100 \pm 8$ & $107 \pm 10$ & $20 \pm 2$ & $86 \pm 14$ \\
\hline & & 15.2 & $138 \pm 10$ & $19 \pm 2$ & $100 \pm 8$ & $96 \pm 11$ & $18 \pm 2$ & $63 \pm 13$ \\
\hline & & 22.9 & $131 \pm 10$ & $24 \pm 2$ & $100 \pm 8$ & $67 \pm 12$ & $17 \pm 3$ & $50 \pm 13$ \\
\hline \multirow[t]{12}{*}{2} & $7.6 \mathrm{~cm}$ & 0 & $110 \pm 10$ & $19 \pm 2$ & $100 \pm 8$ & $75 \pm 14$ & $15 \pm 3$ & $38 \pm 13$ \\
\hline & below grade & 7.6 & $138 \pm 15$ & $27 \pm 3$ & $50 \pm 8$ & $94 \pm 24$ & $17 \pm 6$ & $13 \pm 13$ \\
\hline & & 15.2 & $126 \pm 16$ & $22 \pm 3$ & $44 \pm 8$ & - - & - & $0 \pm 14$ \\
\hline & & 22.9 & $117 \pm 12$ & $22 \pm 2$ & $73 \pm 8$ & - - & - - & $0 \pm 15$ \\
\hline & At grade & 0 & $157 \pm 10$ & $29 \pm 2$ & $100 \pm 8$ & $102 \pm 14$ & $26 \pm 3$ & $43 \pm 14$ \\
\hline & & 7.6 & $135 \pm 12$ & $25 \pm 2$ & $80 \pm 8$ & $72 \pm 17$ & $15 \pm 4$ & $33 \pm 15$ \\
\hline & & 15.2 & $128 \pm 11$ & $24 \pm 2$ & $90 \pm 8$ & $91 \pm 14$ & $33 \pm 3$ & $38 \pm 13$ \\
\hline & & 22.9 & $111 \pm 11$ & $24 \pm 2$ & $90 \pm 8$ & $101 \pm 17$ & $36 \pm 4$ & $33 \pm 15$ \\
\hline & $7.6 \mathrm{~cm}$ & 0 & $153 \pm 10$ & $26 \pm 2$ & $100 \pm 8$ & $57 \pm 11$ & $15 \pm 2$ & $83 \pm 15$ \\
\hline & above grade & 7.6 & $152 \pm 10$ & $26 \pm 2$ & $100 \pm 8$ & $77 \pm 14$ & $20 \pm 3$ & $43 \pm 14$ \\
\hline & & 15.2 & $134 \pm 11$ & $28 \pm 2$ & $90 \pm 8$ & $78 \pm 12$ & $18 \pm 3$ & $50 \pm 13$ \\
\hline & & 22.9 & $127 \pm 11$ & $23 \pm 2$ & $100 \pm 8$ & $35 \pm 17$ & $8 \pm 4$ & $29 \pm 14$ \\
\hline
\end{tabular}

${ }^{2}$ Least squares means ( \pm standard errors) of ten seedlings for F. pennsylvanica and eight seedlings for K. bipinnata.

y***,***, or ns indicates the statistical effect was significant at an alpha level of $0.001,0.01,0.05$, or not significant, respectively. 
Table 1 (continued). Growth responses of Fraxinus pennsylvanica and Koelreuteria bipinnata seedlings grown in $9.3 \mathrm{~L}$ (\#3) containers and then transplanted to field plots with the root collar at grade, $7.6 \mathrm{~cm}(3 \mathrm{in}$.) above grade, or 7.6 $\mathrm{cm}$ ( 3 in.) below grade and maintained in a factorial combination with $0,7.6,15.2$, and $22.9 \mathrm{~cm}(0,3,6$, or 9 in.) layers of mulch over the $0.74 \mathrm{~m}^{2}\left(8 \mathrm{ft}^{2}\right)$ root zone.

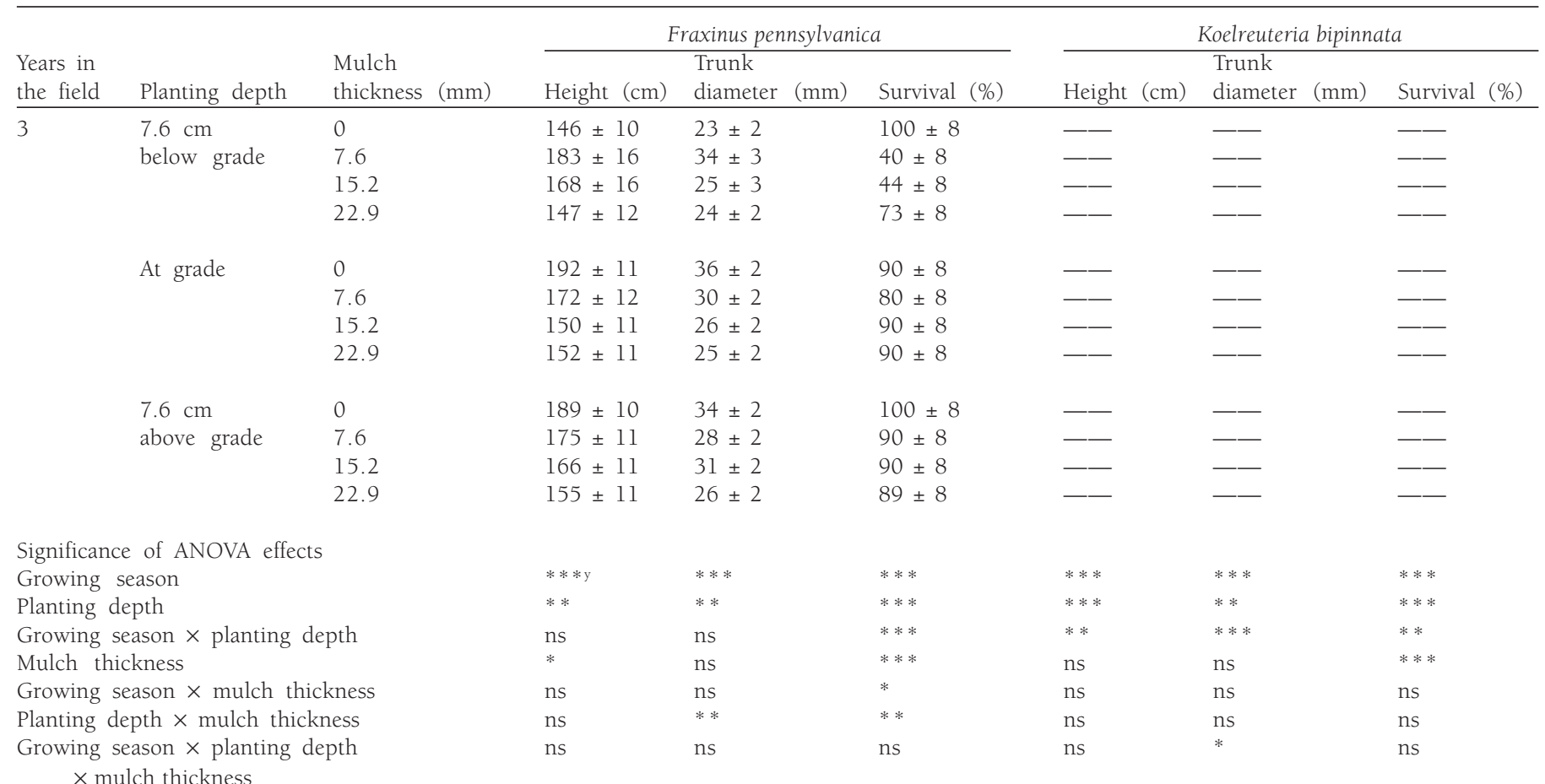

${ }^{z}$ Least squares means ( \pm standard errors) of ten seedlings for F. pennsylvanica and eight seedlings for K. bipinnata.

y***,**, , or ns indicates the statistical effect was significant at an alpha level of 0.001,0.01,0.05, or not significant, respectively.

Table 2. Symptoms of foliar stress during the first growing season after transplant of Fraxinus

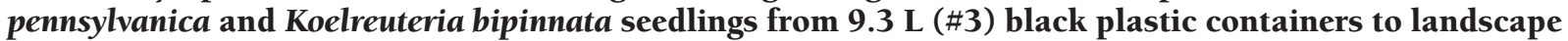
plots with the root collar at grade, $7.6 \mathrm{~cm}(3 \mathrm{in}$.) above grade, or $7.6 \mathrm{~cm}(3 \mathrm{in}$.) below grade and maintained in a factorial combination with $0,7.6,15.2$, and $22.9 \mathrm{~cm}(0,3,6$, or $9 \mathrm{in}$.) layers of mulch over the $0.74 \mathrm{~m}^{2}\left(8 \mathrm{ft}^{2}\right)$ root zone.

\begin{tabular}{llll}
\hline & & $\begin{array}{l}\text { Fraxinus } \\
\text { pennsylvanica } \\
\text { (\% of canopy) }\end{array}$ & $\begin{array}{l}\text { Koelreuteria } \\
\text { bipinnata } \\
\text { (\% of canopy) }\end{array}$ \\
\hline $7.6 \mathrm{~cm}$ below grade & Mulch thickness $(\mathrm{mm})$ & $74 \pm 9.2^{z}$ & $86 \pm 9.3$ \\
& 0 & $77 \pm 9.2$ & $100 \pm 9.9$ \\
& 7.6 & $96 \pm 9.6$ & $100 \pm 9.9$ \\
& 15.2 & $86 \pm 9.6$ & $59 \pm 9.9$ \\
At grade & 22.9 & $57 \pm 9.2$ & $81 \pm 9.9$ \\
& 0 & $83 \pm 9.2$ & $72 \pm 9.3$ \\
7.6 cm above grade & 7.6 & $82 \pm 9.2$ & $83 \pm 10.7$ \\
& 15.2 & $77 \pm 9.2$ & $56 \pm 10.7$ \\
Significance of ANOVA effects & 22.9 & $56 \pm 9.2$ & $71 \pm 9.9$ \\
Planting depth & 0 & $82 \pm 9.2$ & $75 \pm 9.3$ \\
Mulch thickness & 7.6 & $65 \pm 8.7$ & $91 \pm 9.3$ \\
Depth $\times$ mulch & 15.2 & $71 \pm 9.2$ & $* 3$ \\
\hline
\end{tabular}

${ }^{z}$ Least squares means ( \pm standard errors) of ten seedlings for $F$. pennsylvanica or eight seedlings for K. bipinnata.

$y * * *, * * *$, or ns indicates the statistical effect was significant at an alpha level of $0.001,0.01,0.05$, or not significant, respectively. 


\section{Table 3. Main effect of shredded pine bark mulch thick- ness on soil moisture tension measured at a depth of $15.2 \mathrm{~cm}$ (6 in.) in the fine, sandy loam field plots, $n=36$.}

\begin{tabular}{ll}
\hline Mulch thickness $(\mathrm{cm})$ & $\begin{array}{l}\text { Soil moisture } \\
\text { tension }(\mathrm{kPa})\end{array}$ \\
\hline 0 & $-9.1 \mathrm{a}^{*}$ \\
7.6 & $-5.8 \mathrm{a}$ \\
15.2 & $-10.2 \mathrm{a}$ \\
22.9 & $-16.2 \mathrm{~b}$ \\
\hline
\end{tabular}

"Means followed by the same letter are not significantly different

$(P \leq 0.05)$ using the least squares means procedure.

Résumé. La plupart des informations sur les effets de la profondeur de plantation des arbres sont anecdotiques. Il y a un manque concernant les essais à propos des interactions avec d'autres importantes pratiques culturales utilisées lors des travaux d'aménagement paysager. Des semis de frêne (Fraxinus pennsylvanica) et de bougainvillier (Koelreuteria bipinnata) en pot de 2,3 L (contenant \#1) ont été par la suite transplantés dans des pots en plastique noir de 9,3 L (contenant \#3) et développés jusqu'à atteindre la dimension de mise en marché. Le collet racinaire des plants a été maintenu au niveau de la surface du substrat. Les frênes ( $1^{\text {er }}$ mai 2001) et les bougainvilliers (27 avril 2001) ont été tramsplantés au sein de parcelles en plein champ dans des sols argileux avec le collet à $7,6 \mathrm{~cm}$ sous le niveau du sol, au niveau du sol ou avec le collet à 7,6 cm au-dessus du niveau du sol. La profondeur de plantation pour chacune des espèces était de plus combinée avec l'installation d'un paillis d'écorce de pin sur une épaisseur de 0, 7,6, 15,2 ou $22,9 \mathrm{~cm}$, et ce sur une surface de $0,74 \mathrm{~m}^{2}$ autour du tronc. Après deux ans, le taux de survie des bougainvilliers plantés sous le niveau du sol était du tiers de celui des arbres plantés au niveau ou audessus du niveau du sol. Le taux de survie et le diamètre du tronc étaient en interaction avec la profondeur de plantation et l'épaisseur de paillis chez le frêne. La plantation sous le niveau du sol en combinaison avec un paillis diminuait le taux de survie du frêne de 25 à 50\% après trois ans. Lapplication de paillis diminuait le diamètre du tronc chez les frênes plantés au niveau ou au-dessus du niveau du sol. Les potentiels en eau du sol étaient moins négatifs avec $7,6 \mathrm{~cm}$ de paillis $(-5,8 \mathrm{kPa})$ comparativement à un sol à nu $(-9,1 \mathrm{kPa})$; mais l'accroissement de l'épaisseur du paillis jusqu'à 22,9 cm inhibait la pénétration de l'eau d'irrigation ou de l'eau de pluie $(-16,2 \mathrm{kPa})$. Ces données suggèrent que la plantation avec le collet de racines au niveau ou au-dessus du niveau du sol permet d'améliorer le taux de survie et la croissance potentielle du frêne et du bougainvillier, et ce par rapport à une plantation sous le niveau du sol, et que l'application de paillis devrait se faire seulement en couches suffisamment minces pour inhiber la croissance des mauvaises herbes. Les bougainvilliers se sont avérés plus susceptibles que les frênes aux effets adverses d'une plantation sous le niveau du sol et d'une épaisseur de paillis plus importante.

Zusammenfassung. Die meiste erhältliche Information über die Auswirkungen von Pflanztiefen beruht auf Anekdoten. Es fehlen Tests über Interaktionen mit anderen wichtigen Kulturmaßnahmen während der Pflanzung. Fraxinus pennsylvanica H. Marshall, eine Hypoxia-tolerante Art und Koelreuteria bipinnata, ebenfalls Hypoxia-tolerant, wurden aus Samen 2,3 l Containern gezogen, später in 9,3 l schwarze Plastikcontainer umgetopft und zu marktfähiger Größe herangezogen. Die Wurzelkragen der Pflanzen wurden auf Level mit der Oberfläche des Substrats gehalten. Die
Esche wurde am 1.Mai 2001 und die Koelreuteria am 27. April 2001 in lehmigen Freilandboden gepflanzt mit dem Wurzelkragen 7,6 cm über dem Boden, auf Level und 7,6 cm unter der Oberfläche. Die Pflanztiefen waren Kombinationen mit 0, 7.6, 15.2 oder $22.9 \mathrm{~cm}$ mit einer Rindenmulchabdeckung von 0,74 $\mathrm{m}^{2}$ um jeden Baum. Nach 2 Jahren war betrug die Überlebensrate der unter Bodenniveau gepflanzten Koelreuteria 1/3 derjenigen auf Level bzw. über dem Boden gepflanzten Bäume. Es gab bei der Esche Interaktionen zwischen der Überlebensrate und dem Durchmesserzuwachs auf der einen Seite und den Pflanztiefen und Mulchdicke. Das Pflanzen unter Level in Kombination mit Mulchen reduzierte das Überleben der Esche zu 25-50 \% nach 3 Jahren. Das Mulchen reduzierte den Baumdurchmesserzuwachs bei allen Eschen, die auf bzw. über Niveau gepflanzt wurden. Die durchschnittlichen Bodenwasserpotentiale waren weniger negativ bei 7,7 c Mulchauflage im Vergleich zu nacktem Boden, aber die stärkere Mulchauflage bis zu 22,9 cm verhinderte die Penetration von Regen bzw. Bewässerung. Diese Daten verdeutlichen, dass Pflanzungen auf oder über Bodenniveau die Überlebensrate und das Wachstumspotential von Esche und Koelreuteria im Vergleich zu der anderen Pflanzung verbessern und dass die Mulchapplikationen nur als dünner Auftrag zu Verhinderung der Verkrautung durchgeführt werden sollte. Die Koelreuteria waren empfindlicher gegenüber dem umgekehrten Effekt von Pflanzung unter Niveau und dicker Mulchauflage als die Eschen.

Resumen. La mayoría de la información disponible sobre los efectos de las profundidades de plantación en los árboles es anecdótica. Existe un vacío de pruebas de las interacciones con otras importantes prácticas culturales implementadas durante el establecimiento de los árboles en un paisaje. El fresno (Fraxinus pennsylvanica H. Marshall, una especie tolerante) y el árbol 'lluvia de oro' (Koelreuteria bipinnata A.R. Franchet, una especie intolerante) crecieron a partir de semilla en contenedores (\#1) de 2.3-L; fueron trasplantados posteriormente a contenedores de plástico negro (\#3) de 9.3-L hasta alcanzar un tamaño comercial. Las coronas de la raíz de las plantas se mantuvieron a nivel con la superficie del sustrato. Los fresnos (1 Mayo 2001) y los árboles 'lluvia de oro' (27 Abril 2001) fueron trasplantados a macetas de arcilla con las coronas de las raíces a $7.6 \mathrm{~cm}$. (3 pulg.) arriba del nivel del suelo, a nivel, y a $7.6 \mathrm{~cm}$. (3 pulg.) abajo del nivel. Las profundidades de plantación para cada especie estuvieron en combinaciones factoriales con 0, 7.6, 15.2, o 22.9 $\mathrm{cm}$. (0, 3, 6, o 9 pulg., respectivamente) de mulch de corteza de pino, cubriendo $0.74 \mathrm{~m}^{2}$ (8 pies cuadrados) de suelo bajo cada árbol. Después de 2 años, la supervivencia de los 'lluvia de oro' plantados bajo el nivel fue una tercera parte de los plantados a nivel o arriba del mismo. La supervivencia y diámetro del tronco interactuó con la profundidad de plantación y el grosor del mulch para el fresno. La plantación abajo del nivel en combinación con el mulch redujo la supervivencia del fresno 25\% a 50\% después de 3 años. Las aplicaciones de mulch redujeron los diámetros del tronco de los fresnos plantados a nivel o arriba del mismo. Los potenciales hídricos promedio del suelo fueron negativos con 7.6 $\mathrm{cm}$. (3 pulg.) de mulch (-5.8 kPa) comparados con suelo desnudo (-9.1 $\mathrm{kPa}$ ); pero el incremento del grosor del mulch a $22.9 \mathrm{~cm}$. (0 pulg.) inhibió la penetración de agua de riego o lluvia $(-16.2 \mathrm{kPa})$. Estos datos sugieren que la plantación con la corona de la raíz a nivel o arriba del mismo mejora la supervivencia y el crecimiento potencial de fresno y 'lluvia de oro', con relación a la plantación bajo el nivel y que las aplicaciones de mulch deberán ser solamente en capas delgadas suficientes para inhibir las hierbas. Los árboles 'lluvia de oro' fueron más susceptibles que los fresnos a los efectos adversos de la instalación bajo el nivel y el exceso de mulch. 